\title{
Causes of the drastic loss of genetic variation in the Critically Endangered Formosa landlocked salmon of Taiwan
}

\author{
Te-Hua Hsu ${ }^{1}$, Keisuke Takata ${ }^{2}$, Hiroshi Onozato ${ }^{3}$, Jin-Chywan Gwo ${ }^{1, *}$ \\ ${ }^{1}$ Department of Aquaculture, National Taiwan Ocean University, Keelung 20224, Taiwan \\ ${ }^{2}$ Faculty of Science, Shinshu University, Matsumoto-city, Nagano 390-8621, Japan \\ ${ }^{3}$ Matsumoto Institute of Microorganisms Co. Ltd., Matsumoto-city, Nagano 390-1241, Japan
}

\begin{abstract}
The use of hatchery-reared fish to replenish existing threatened wild populations has been shown to reduce or change the natural genetic diversity of the wild populations. In this study, the genetic diversity of wild Formosa landlocked salmon Oncorhynchus formosanus in its main habitat of the Chichiawan Stream in Taiwan was examined after a large-scale escape of hatcherycultivated fish. Approximately 3000 individuals (the descendants of only 5 pairs of wild salmon) escaped from an old hatchery when Typhoon Ariel breached the hatchery in the fall of 2004. The genetic diversity of the wild population was extremely low at that time, and declined further between 2004 and 2008 following the escape of hatchery fish. We hypothesize that the decline in genetic diversity of the wild population was mainly caused by a population bottleneck in 2005, and that genetic homogeneity since 2005 was caused by breeding of the escaped hatchery fish (which showed low genetic diversity) that survived the floods of 2004. This supports the possibility that the drastic decline in genetic diversity between 2004 and 2008 was caused by the genetic effects of the escaped hatchery fish, and demonstrates the risk of introducing hatchery fish into the wild.
\end{abstract}

KEY WORDS: Taiwan · Amplified fragment length polymorphism - AFLP · Genetic diversity · Conservation $\cdot$ Endangered

\section{INTRODUCTION}

The Formosa landlocked salmon Oncorhynchus formosanus (Jordan \& Oshima 1919) is an endangered species endemic to the island of Taiwan. Most of the population is confined to a $7 \mathrm{~km}$ section within the headwaters of the Chichiawan Stream (Jan et al. 1990, Ho \& Gwo 2010), in the upper reaches of the Tachia River (Teng 1959, Watanabe \& Lin 1985, Jan et al. 1990). The Formosa landlocked salmon was previously known as $O$. masou formosanus, a subspecies of Japanese masu salmon $O$. masou masou (Jordan \& Oshima 1919, Behnke et al. 1962, Watanabe \& Lin 1985), and as such, was considered to be the southernmost natural masu salmon population in the world. However, several morphological and

\footnotetext{
${ }^{*}$ Corresponding author: gwojc@hotmail.com
}

molecular studies have recently demonstrated that Formosa landlocked salmon should be treated as an independent species, $O$. formosanus (Gwo et al. 2008, Nakabo 2009, Ho \& Gwo 2010, Ho \& Shao 2011). The IUCN Red List also treats it as an independent species (Kottelat 1996). This species is considered a glacial relic and became landlocked in the streams of Taiwan as a result of a complex process of glaciation, mountain range uplifting, de-glaciation, and evolution from anadromous ancestors to a landlocked population (Behnke et al. 1962).

Due to a combination of factors including habitat loss and degradation, pollution, overexploitation, natural catastrophes, and global warming, the remaining Formosa landlocked salmon population was listed as an endangered species by the Taiwan Gov-

() The authors 2015. Open Access under Creative Commons by Attribution Licence. Use, distribution and reproduction are unrestricted. Authors and original publication must be credited. 
ernment in 1989 (Lin et al. 1990, Anonymous 2000, Lin et al. 2006), while the IUCN lists the species as Critically Endangered. In 1992, the entire population was estimated at fewer than 300 individuals. Because the population was at a high risk of extinction, approximately 1000 hatchery fish fry, (approximately 40 to $50 \mathrm{~mm}$ ) were released into Chichiawan Stream between 1994 and 1999. However, the survival rate of the fry was extremely low. In order to maintain the wild population, a complete aquaculture system was established by Shei-Pa National Park in 2003 (Liao 2008). This system included the hatchery salmon and the use of adult-produced eggs which were hatched as larvae for rearing in captivity.

Five pairs of wild Formosa landlocked salmon were collected in the year 2000 to serve as founders; these fish produced 15000 juveniles for the supplementation program (Liao 2008). A total of approximately 5000 captive-bred (i.e. hatchery-cultivated) Formosa landlocked salmon were propagated through the complete aquaculture system, and then confined and accumulated in an old hatchery for 4 consecutive years (2000 to 2004) (Liao 2008, Lin 2010). Although both Taiwanese and Japanese scientists proposed that the hatchery-cultivated salmon should not be released into historical habitats in order to avoid potentially damaging genetic effects, at least 3271 (3000 age 1, 8 to $20 \mathrm{~cm}$ total body length; 250 age 2, $>20 \mathrm{~cm}$; and 21 age 3) of the captive-bred salmon escaped from the old hatchery when Typhoon Ariel hit in the fall of 2004 (Lin et al. 2006, Liao 2008).

The use of hatchery-reared fish as a technique to replenish existing threatened wild populations has long been discussed (Hilborn \& Eggers 2000, 2001, Brown \& Day 2002, Araki et al. 2007, Buhle et al. 2009, Araki \& Schmid 2010). Loss of genetic diversity in salmonids reportedly occurs when the effective number of parents is reduced to $<100$ (Ryman \& Laikre 1991, Cloud \& Thorgaard 1993, Allendorf \& Luikart 2007, Araki et al. 2007, 2009). Massive releases or escapes of hatchery-cultivated salmon have been shown to reduce or change the natural genetic diversity among wild populations (e.g. Salmo spp., Araki \& Schmid 2010, Jensen et al. 2010; Oncorhynchus spp., Kawamura et al. 2007, Buhle et al. 2009, Araki \& Schmid 2010, Heggenes et al. 2011). Biological problems that may arise following hatchery releases include (1) changes in the genetic diversity of wild populations, (2) risk of introduction of disease pathogens to wild stock, and (3) risk of overstocking the wild capacity of streams (Brown \& Day 2002, Naish et al. 2007, Buhle et al. 2009, Jensen et al. 2010).
Genetic diversity is correlated with population viability and related to the ability of the species to cope with future environmental changes. It is important for endangered species to retain as much genetic diversity as possible to enhance their chances of recovery (Cloud \& Thorgaard 1993, Brown \& Day 2002, Allendorf \& Luikart 2007). Understanding the genetic makeup of an 'at-risk' population is extremely important for genetic enhancement programs in order to maximize the advantages of captive breeding while avoiding potential inbreeding and random genetic drift drawbacks (Taniguchi 2003, Allendorf \& Luikart 2007, Araki et al. 2007). Thus, for successful conservation it is extremely important to monitor genetic variability in the wild population as well as in the hatchery stock.

Previous genetic studies of Formosa landlocked salmon using mitochondrial control region sequences and 23 microsatellite DNA loci were not useful in terms of revealing genetic structure because of the low genetic diversity of the population (Tzeng et al. 2006, Chang et al. 2009, Hsu et al. 2010). Here, we used amplified fragment length polymorphism (AFLP) technology to investigate the potential genetic effects on the wild population of the massive escape of hatchery-cultivated salmon that occurred in 2004. AFLP is a multi-locus PCR-based DNA fingerprinting technique that provides reliable, rapid, economic and robust analysis of population genetics (Liu \& Cordes 2004, Bensch \& Åkesson 2005, Falush et al. 2007). In addition, AFLP is capable of generating a large number of loci per assay and has shown some informative loci in a previous study of Formosa landlocked salmon (Gwo et al. 2008, Hsu et al. 2010). Samples taken prior to and following the flooding event caused by Typhoon Ariel were examined along with reference samples from the hatchery-cultivated captive stock were examined. Our results support the possibility that the drastic decline of genetic diversity between 2004 and 2008 was caused by the genetic effects of escaped hatchery fish, and highlights the risk of releasing hatchery fish into the wild.

\section{MATERIALS AND METHODS}

\section{Study area, sample collection and DNA extraction}

This study was conducted in the Chichiawan Stream, in the upper tributary of the Tachia River in central Taiwan (Fig. 1). To save the endangered Formosa landlocked salmon from extinction, the Chichiawan Stream was designed as a protected refuge 


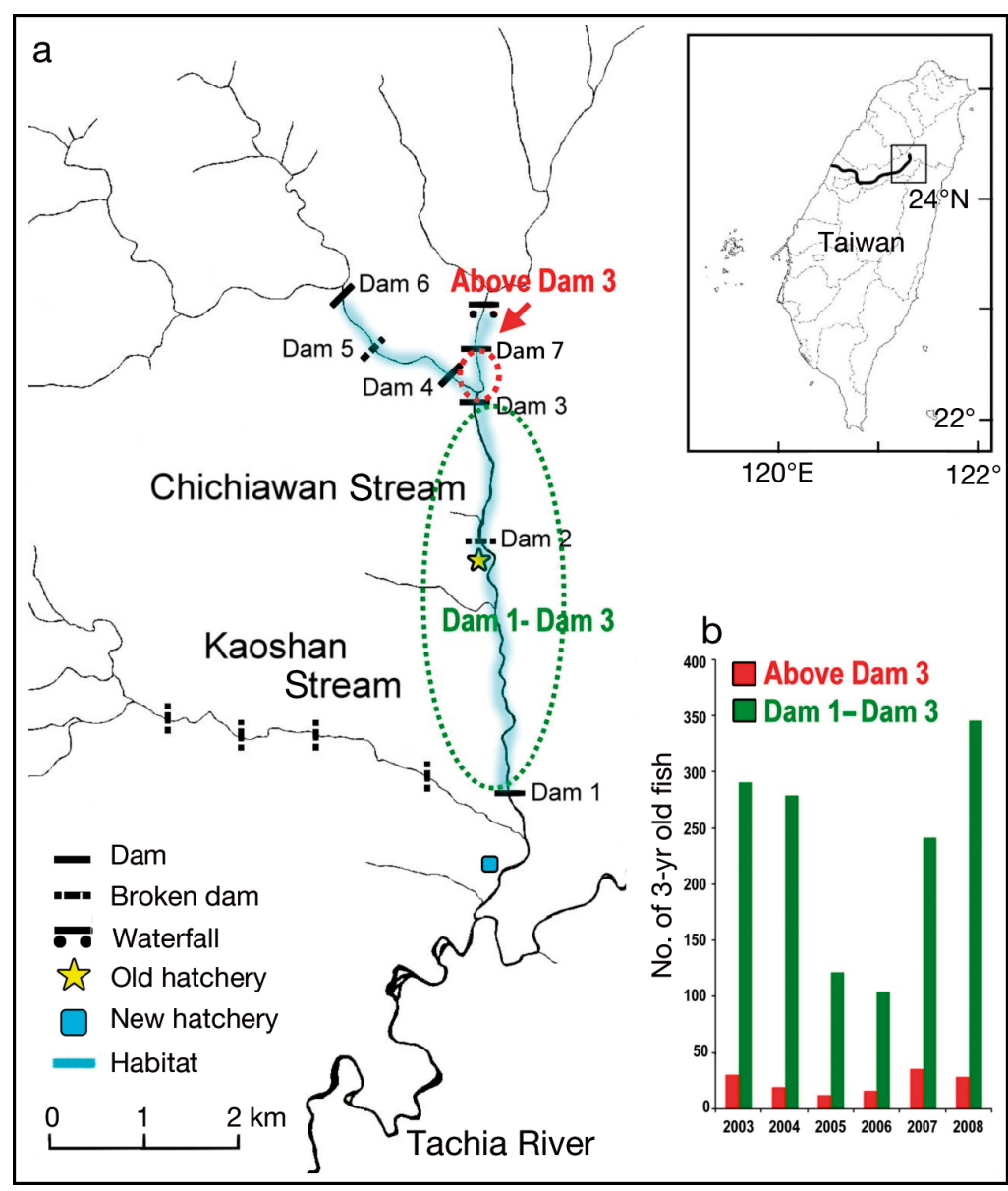

Fig. 1. (a) Sampling areas of Formosa landlocked salmon Oncorhynchus formosanus within the upper tributary of the Tachia River in central Taiwan. The old hatchery ( 5 ) near the broken dam (Dam 2) is located midstream on the Chichiawan Stream. The new hatchery (口) was established in 2006. Inset shows the location of Chichiawan Stream in Taiwan. (b) Estimated number of 3 yr old fish from 2003 to 2008 (data from Lin 2010)

area, and various conservation efforts (including hatchery propagation) have been conducted in that area since the 1990s (Lin et al. 2006).
There are 5 impassable check dams (Dams 1, 3, 4, 6, and 7) in the stream that were constructed in the 1970s for sediment, erosion and flood control (Lin et al. 1990, Lin et al. 2006). The area between Dams 1 and 3 (a distance of $4349 \mathrm{~m}$ ) is the main habitat of Formosa landlocked salmon (Lin et al. 1990, Tzeng 2004, Lin et al. 2006). The upper end of the collecting section is bounded by Dam 3 (12 m high), while the lower end is bounded by Dam 1 (15 m high). Dam 2 (located $1500 \mathrm{~m}$ downstream from Dam 1, midway between Dams 1 and 3) was damaged by storms in the 1990s, such that fish can swim freely through Dam 2.

In 2004, 2005, 2006, and 2008, wild Formosa landlocked salmon were collected between Dams 1 and 3 in SheiPa National Park (Fig. 1). At least 28 fish (total length ranging from 15 to $26 \mathrm{~cm}$ ) were collected each year with casting nets. In 2004, the fish were collected before the old hatchery was breached by Typhoon Ariel. In 2005, 2006, and 2008, the fish were captured during the breeding season (October to November). In May 2006, 139 wild fish were additionally sampled in the upper reaches of the Chitchiawan Stream (Fig. 1, Table 1). A total of 30 hatchery-cultivated fish (pre-typhoon) were used as controls.

Following capture, part of the adipose fin of all fish was clipped (about $20 \mathrm{mg}$ ), and fin samples were preserved in 95\% ethanol. Fish were released into the original capture sites immediately after the fin was clipped. Total

Table 1. Number of bands detected and polymorphic bands scored from amplified fragment length polymorphism analysis of 3 selective-primer pairs in wild and hatchery-cultivated Formosa landlocked salmon Oncorhynchus formosanus over 4 yr $(2004,2005,2006$, and 2008)

\begin{tabular}{|lcccccc|}
\hline & $\begin{array}{c}2004 \\
\text { Dams 1-3 } \\
\text { (pre-typhoon) }\end{array}$ & $\begin{array}{c}2005 \\
\text { Dams 1-3 }\end{array}$ & $\begin{array}{c}2006 \\
\text { Dams 1-3 }\end{array}$ & $\begin{array}{c}2006 \\
\text { Above Dam 3 }\end{array}$ & $\begin{array}{c}\text { Hatchery- } \\
\text { cultivated } \\
\text { (pre-typhoon) }\end{array}$ & $\begin{array}{c}2008 \\
\text { Dams 1-3 }\end{array}$ \\
\hline Sample size & 30 & 28 & 62 & 7 & 18 & 30 \\
Total bands & 191 & 177 & 178 & 196 & 161 & 161 \\
Polymorphic bands & 39 & 34 & 36 & 50 & 3 \\
Similarity values $(S)$ & 0.968 & 0.977 & 0.992 & 0.988 & 0.998 & 0.999 \\
Genetic diversity $\left(H_{\mathrm{e}} \pm \mathrm{SD}\right)$ & $0.056 \pm 0.009$ & $0.037 \pm 0.008$ & $0.013 \pm 0.003$ & $0.020 \pm 0.003$ & $0.003 \pm 0.002$ & $0.001 \pm 0.001$ \\
Shannon's index $(I \pm \mathrm{SD})$ & $0.086 \pm 0.013$ & $0.060 \pm 0.012$ & $0.026 \pm 0.005$ & $0.041 \pm 0.006$ & $0.004 \pm 0.003$ & $0.003 \pm 0.002$ \\
\hline
\end{tabular}


DNA was extracted from the adipose fin $(<10 \mathrm{mg})$ using proteinase-K digestion and the phenol-chloroform-isoamyl alcohol method (Sambrook \& Russell 2000) with slight modifications. DNA concentration was measured with a UV spectrophotometer. The quality of extracted DNA was assessed by $1.0 \%$ agarose gel electrophoresis with ethidium bromide.

\section{AFLP analysis}

Procedures for AFLP analysis were based on Hsu et al. (2010). Fingerprint patterns were visualized on a $5 \%$ denaturing polyacrylamide gel using the silver staining method. DNA templates for AFLP reactions were generated by restriction digestion and ligation. Initially, about $100 \mathrm{ng}$ of total DNA was digested with $5 \mathrm{U}$ of EcoRI and Tru9I (Promega) in 1× buffer C at 37 and $65^{\circ} \mathrm{C}$ for $3 \mathrm{~h}$, respectively. Restriction fragments were ligated to EcoRI and MseI adaptors. Ligation was followed by pre-amplification and selective amplification. The selective amplification was performed using 3 pairs of primers: E-AGC/M-CTT, E-AGC/M-CTG, and E-AAG/M-CTT. The amplification products were electrophoresed on a $5 \%$ denaturing polyacrylamide gel.

Band sizes were estimated using a standard AFLP DNA ladder and analyzed using the Imaging Analyzing System (HP ScanJet 5370c). The AFLP bands were scored for presence (1) or absence (0), and transformed into a 0/1 binary character matrix. A similarity index $(S)$ was calculated according to the Dice similarity coefficient (Dice 1945) using Excel Visual Basic for Applications (VBA). Expected genetic diversity $\left(H_{\mathrm{e}}\right)$, Shannon's index $(I)$, Nei's genetic distance ( $D_{\text {si }}$ allele frequency based), mean population binary genetic distance (GD), pairwise Phi $\left(\Phi_{\mathrm{ST}}\right)$ calculated based on GD and principal coordinates analysis (PCoA) were performed using GENALEX v.6.41 (Peakall \& Smouse 2006).

Pairwise $F_{\text {ST }}$ among AFLP loci was estimated using the software HICKORY (Holsinger \& Lewis 2007) to generate $\theta$-II values that are directly comparable to the $\theta$ estimator of the $F_{\mathrm{ST}}$ (Weir \& Cockerham 1984). Significant differentiation is revealed if the $F_{\mathrm{IS}}=0$ model is preferred to the $F_{\mathrm{ST}}=0$ model based on the smaller deviance information criterion (DIC) (Coyer et al. 2011).

Model-based (Bayesian-Markov Chain Monte Carlo) clustering analysis was performed using STRUCTURE v.2.2 (Falush et al. 2007) to further elucidate the genetic structure of the population. Three independent runs were carried out for the total data set for values of $K$ (i.e. clusters of individuals) ranging from 1 to 6 . All runs were based on 100000 iterations after a burn-in period of 100000 iterations. The best estimation of $K$ (the number of $K$ groups) were conducted according to Evanno et al. (2005) using STRUCTURE HARVESTER (see Fig. S1 in the Supplement at www.int-res.com/articles/suppl/n027 p277_supp.pdf) (Earl \& vonHoldt 2012). Summation and graphical representation of STRUCTURE results were generated using CLUMPAK (Kopelman et al. 2015).

\section{Mitochondrial DNA and microsatellite analysis}

All specimens were used in mitochondrial DNA analysis. The mitochondrial ND5 gene was amplified using the primer pair ND5-1F, 5'-TAC CCC AAT TGC CCT GTA CG-3' and ND5-3R, 5'-CTA ACA CGT GGG TTA GGT CG-3', yielding approximately 561 base pairs (Kitanishi et al. 2007). Amplifications for the ND5 gene were carried out using an initial denaturation of $94^{\circ} \mathrm{C}$ for $4 \mathrm{~min}$, followed by 35 cycles of $94^{\circ} \mathrm{C}$ for $60 \mathrm{~s}, 54^{\circ} \mathrm{C}$ for $60 \mathrm{~s}$ and $72^{\circ} \mathrm{C}$ for $120 \mathrm{~s}$, followed by a final extension at $72^{\circ} \mathrm{C}$ for $3 \mathrm{~min}$. DNA samples were purified using the QIAquick gel extraction kit (Qiagen). Sequences were determined using the ABI 3100 automated DNA sequencer (Applied Biosystems), edited and aligned in DNA Baser (Heracle BioSoft S.R.L.; www.dnabaser.com).

All specimens were also used in microsatellite analysis. A total of 23 microsatellite primers sets developed from masu, Atlantic and Pacific salmon were used: Omi17, Omi30, Omi34, Omi43, Omi50, Omi57, Omi65, Omi69, Omi70, Omi77, Omi87, Omi102, Omi109, Omi112, Omi179, Oma 01, Oma 02, Oma3ke, Oma4my, Omy207, Oneu11, Ssa197 and Ssa 293 (Hsu et al. 2010). Procedures for microsatellite analysis were based on Hsu et al. (2010). Tests to determine the observed genetic diversity or heterozygosity $\left(H_{\mathrm{o}}\right), H_{\mathrm{e}}$, and chi-squared Hardy-Weinberg equilibrium (HWE) were performed using GENALEX v.6.41 (Peakall \& Smouse 2006).

\section{RESULTS}

The results of our preliminary study are in line with the findings of previous genetic studies of Formosa landlocked salmon. Using 23 microsatellite DNA loci and mtDNA (ND5), we were unable to reveal any genetic diversity (Tables S1 \& S2 in the Supplement at www.int-res.com/articles/suppl/n027p277_supp.pdf). 
Table 2. Pairwise population matrix of mean population binary genetic distance (GD; below the diagonal, light gray) and Nei's genetic distance $\left(D_{\mathrm{s}}\right.$ a above the diagonal, dark gray) from amplified fragment length polymorphism (AFLP) analysis of 3 selective-primer pairs in wild and hatchery-cultivated Formosa landlocked salmon Oncorhynchus formosanus over 4 yr (2004, 2005, 2006, and 2008). Data for 2004 and 'Hatchery-cultivated' are pre-typhoon

\begin{tabular}{|c|c|c|c|c|c|c|}
\hline & $\begin{array}{c}2004 \\
\text { Dams 1-3 }\end{array}$ & $\begin{array}{c}2005 \\
\text { Dams 1-3 }\end{array}$ & $\begin{array}{c}2006 \\
\text { Dams 1-3 }\end{array}$ & $\begin{array}{c}2006 \\
\text { Above Dam } 3\end{array}$ & $\begin{array}{l}\text { Hatchery- } \\
\text { cultivated }\end{array}$ & $\begin{array}{c}2008 \\
\text { Dams 1-3 }\end{array}$ \\
\hline 2004 Dams 1-3 & - & 0.010 & 0.008 & 0.005 & 0.007 & 0.008 \\
\hline 2005 Dams 1-3 & 11.231 & - & 0.003 & 0.005 & 0.006 & 0.008 \\
\hline 2006 Dams 1-3 & 7.983 & 6.297 & - & 0.002 & 0.003 & 0.004 \\
\hline 2006 Above Dam 3 & 8.371 & 6.893 & 3.222 & - & 0.003 & 0.004 \\
\hline Hatchery-cultivated & 7.133 & 5.603 & 1.536 & 2.307 & - & 0.002 \\
\hline 2008 Dams 1-3 & 7.582 & 5.657 & 1.694 & 2.616 & 0.800 & - \\
\hline
\end{tabular}

Only one polymorphic microsatellite loci (Omi43) was found in this study that showed genetic diversity or heterozygosity (Table S1). The observed and expected genetic diversity obtained from this microsatellite in wild and hatchery-cultivated Formosa landlocked salmon in 2004, 2005, and 2006 ranged from 0.15 to 0.29 (Table S1). There were no significant deviations from the Hardy-Weinberg equilibrium. Additionally, 42 wild Formosa landlocked salmon individuals captured in 2004 between Dams 1 and 3 all possessed the same haplotype (Table S2).

Using 3 AFLP primer pairs (E-AGC/M-CTT, EAGC/M-CTG and E-AAG/M-CTT), a total of 196 scorable loci (bands) were detected in 227 wild Formosa landlocked salmon individuals over the $4 \mathrm{yr}$ of this study $(2004,2005,2006$, and 2008) (Table 1). The total bands (i.e. number of loci) generated from wild and hatchery-cultivated fish were similar and ranged from 161 to 196 (Table 1). However, the number of polymorphic bands for wild fish between Dams 1 and 3 decreased from 39 in 2004 (pre-typhoon) to 3 in 2008 (Table 1). Wild fish above Dam 3 in 2006 had the highest number of polymorphic bands (50), whereas the wild fish between Dams 1 and 3 in 2008 had the fewest number of bands (3). Hatcherycultivated fish (pre-typhoon) had the lowest number of polymorphic bands (2) in all populations investigated (Table 1).

The $H_{\mathrm{e}}$ of the wild population between Dams 1 and 3 ranged from 0.001 to 0.056 , with $S$ values ranging from 0.968 to 0.999 and $I$ ranging from 0.003 to 0.086 (Table 1). $S$ values increased from 0.968 in 2004 to 0.999 in 2008, whereas the 2 population genetic diversity parameters $\left(H_{\mathrm{e}}\right.$ and $\left.I\right)$ decreased drastically to almost 0 between 2004 and 2008. The wild population above Dam 3 in 2006 had higher genetic diversity than the wild population between Dams 1 and 3 and the hatchery-cultivated stock (pre-typhoon) (Table 1).

In the analysis of pairwise GD and $D_{\mathrm{s}}$, the pairwise combination of hatchery-cultivated fish and wild fish between Dams 1 and 3 in 2008 showed the lowest values (GD $=0.800$ and $D_{\mathrm{s}}=0.002$ ), whereas the pairwise combination of wild fish between Dams 1 and 3 in 2004 and 2005 showed the highest values (GD = 11.231 and $D_{\mathrm{s}}=0.010$ ) (Table 2). Similarly, lower values of $\Phi_{\mathrm{ST}}$ and $F_{\mathrm{ST}}$ were found in pairwise combinations among hatchery-cultivated fish, wild fish between Dams 1 and 3 in 2006 and 2008, and wild fish above Dam 3 in 2006 ( $\Phi_{\mathrm{ST}}: 0$ to $0.042 ; F_{\mathrm{ST}}: 0.00077$ to 0.00172 ) (Table 3), whereas higher values of $\Phi_{\mathrm{ST}}$ and $F_{\mathrm{ST}}$ were found in pairwise combinations of wild fish between Dams 1 and 3 in 2004 and others $\left(\Phi_{\mathrm{ST}}: 0.038\right.$ to $0.071 ; F_{\mathrm{ST}}: 0.02497$ to 0.07087 ) (Table 3).

The allele frequency of amplified polymorphic loci was most variable in wild fish between Dams 1 and 3 in 2004 (pre-typhoon) than in any other populations investigated (Fig. 2). Erratic behaviour of allele frequencies is to be expected, both due to genetic drift and as an effect of limited sample size. However, most of the amplified polymorphic loci became monomorphic in wild fish between Dams 1 and 3 after 2004. Eighteen (loci 28 to 45) and 5 (loci 18 to 22 ) of the amplified polymorphic loci in 2004 became monomorphic in 2005 (the ratio of individuals showing AFLP bands: $\mathrm{F}=100 \%$, bands present; $\mathrm{F}=0 \%$, bands absent) (Fig. 2). By 2008, only 3 loci $(24,25$ and 48$)$ were polymorphic in wild fish between Dams 1 and 3 (Fig. 2). In 2006, the polymorphic loci of wild fish above Dam 3 were more variable than those of wild fish in the corresponding year between Dams 1 and 3. Additionally, only 2 loci $(25$ and 48$)$ were polymorphic in the hatcherycultivated population (Fig. 2). 
Table 3. Pairwise $F_{\mathrm{ST}}\left(\theta-\mathrm{II}\right.$ estimator, Holsinger \& Lewis 2007 ; below the diagonal, light gray) and Phi ${ }_{\mathrm{ST}}\left(\Phi_{\mathrm{ST}}\right.$; above the diagonal, dark gray) from amplified fragment length polymorphism (AFLP) analysis of 3 selective-primer pairs in wild and hatcherycultivated Formosa landlocked salmon Oncorhynchus formosanus over 4 yr (2004, 2005, 2006, and 2008). Data for 2004 and 'Hatchery-cultivated' are pre-typhoon. ${ }^{*} \mathrm{p}<0.01$ (significance tests were performed in $\Phi_{\mathrm{ST}}$ analysis); ${ }^{+}$Significant difference between populations (best-fit model: $F_{\mathrm{IS}}=0$ )

\begin{tabular}{|c|c|c|c|c|c|c|}
\hline & $\begin{array}{c}2004 \\
\text { Dams 1-3 }\end{array}$ & $\begin{array}{c}2005 \\
\text { Dams 1-3 }\end{array}$ & $\begin{array}{c}2006 \\
\text { Dams 1-3 }\end{array}$ & $\begin{array}{c}2006 \\
\text { Above Dam } 3\end{array}$ & $\begin{array}{l}\text { Hatchery- } \\
\text { cultivated }\end{array}$ & $\begin{array}{c}2008 \\
\text { Dams 1-3 }\end{array}$ \\
\hline 2004 Dams 1-3 & - & $0.064^{*}$ & $0.071^{*}$ & $0.048^{*}$ & $0.038^{*}$ & $0.064^{*}$ \\
\hline 2005 Dams 1-3 & $0.06424^{+}$ & - & $0.063^{*}$ & $0.071^{*}$ & $0.049^{*}$ & $0.066^{*}$ \\
\hline 2006 Dams 1-3 & $0.07087^{+}$ & $0.04670^{+}$ & - & 0.002 & 0.000 & $0.029^{*}$ \\
\hline 2006 Above Dam 3 & $0.04730^{+}$ & $0.03914^{+}$ & 0.00084 & - & 0.000 & $0.042^{*}$ \\
\hline Hatchery-cultivated & $0.02497^{+}$ & $0.01737^{+}$ & 0.00077 & 0.00075 & - & 0.011 \\
\hline 2008 Dams 1-3 & $0.06380^{+}$ & $0.04726^{+}$ & 0.00074 & 0.00172 & 0.00111 & - \\
\hline
\end{tabular}

PCoA revealed 2 (small and large) main clusters (Fig. 3). Sixty-six percent (20/30) of the individuals sampled in 2004 (pre-typhoon) between Dams 1 and 3 were concentrated inside the small oval area, while the rest of the individuals were spread over a relatively larger portion of the 2-dimensional space (as shown in Fig. 3). These observations suggest a lower level of genetic diversity (variation) in hatchery-cultivated (pre-typhoon) and wild fish collected between Dams 1 and 3 in 2008 compared to individuals collected in 2004 (pre-typhoon), 2005, and 2006 either from be- tween Dams 1 and 3 or above Dam 3 (Fig. 3). Measurement of genetic diversity indicates that the diversities of wild fish between Dams 1 and 3 in 2004 (pretyphoon), 2005, and 2006 were clearly higher than those of hatchery-cultivated individuals (pre-typhoon) and wild fish between Dams 1 and 3 in 2008. In 2006, the genetic diversity above Dam 3 appeared to be only a subset of the diversity originally present in the population below Dam 3; in the PCoA plot (Fig. 3), some individuals of the below-dam 2004 sample cluster were further apart from the 'oval area' than the

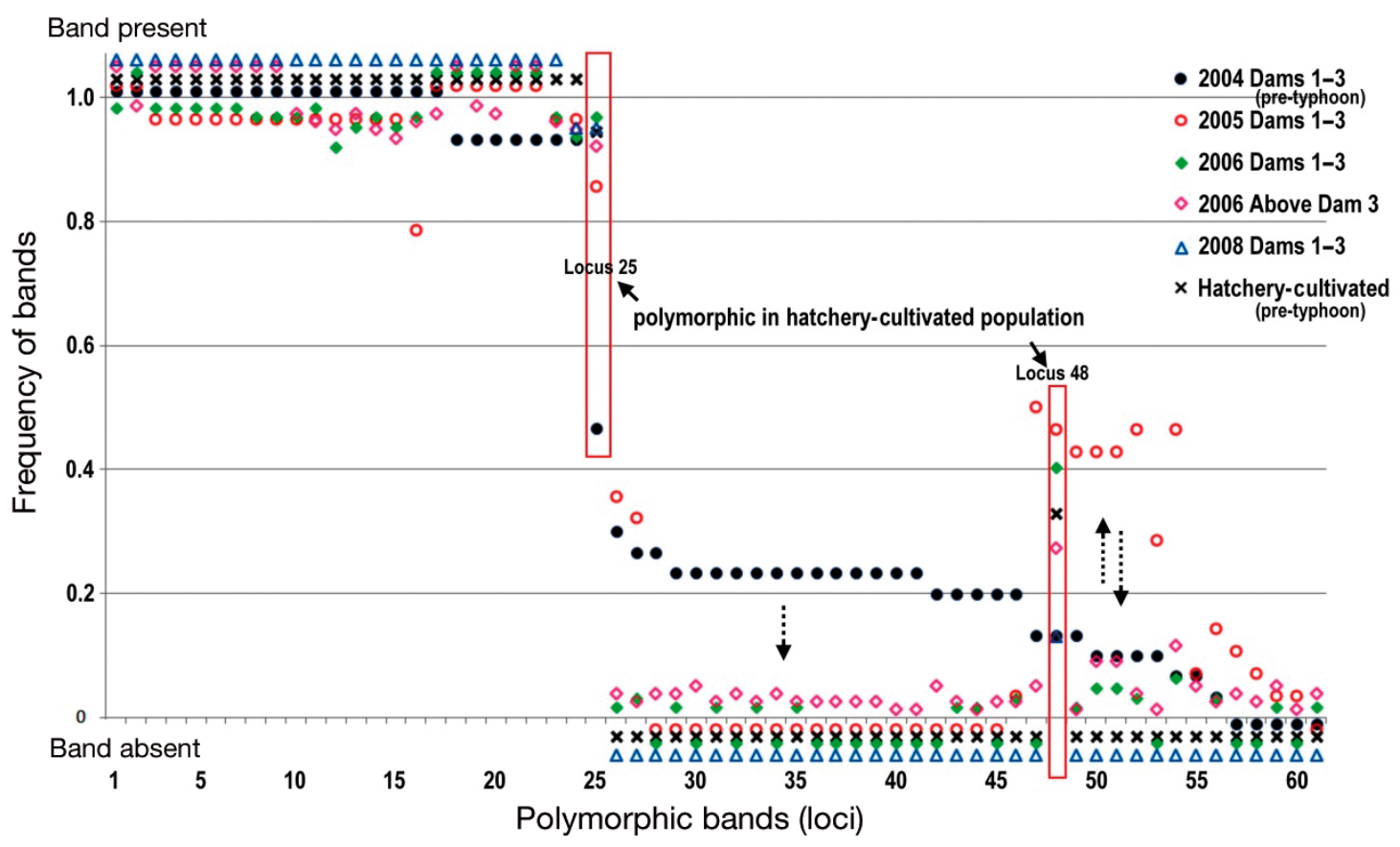

Fig. 2. Frequency of bands (amplified polymorphic loci) in all populations of Formosa landlocked salmon Oncorhynchus formosanus. Only 2 loci (25 and 48) were polymorphic in the hatchery-cultivated population. In 2006, the polymorphic loci of the wild fish above Dam 3 were more variable than wild fish between Dams 1 and 3 . After the flooding event (following the typhoon of 2004), only 3 loci (24, 25 and 48) were polymorphic in wild fish between Dams 1 and 3 in 2008 


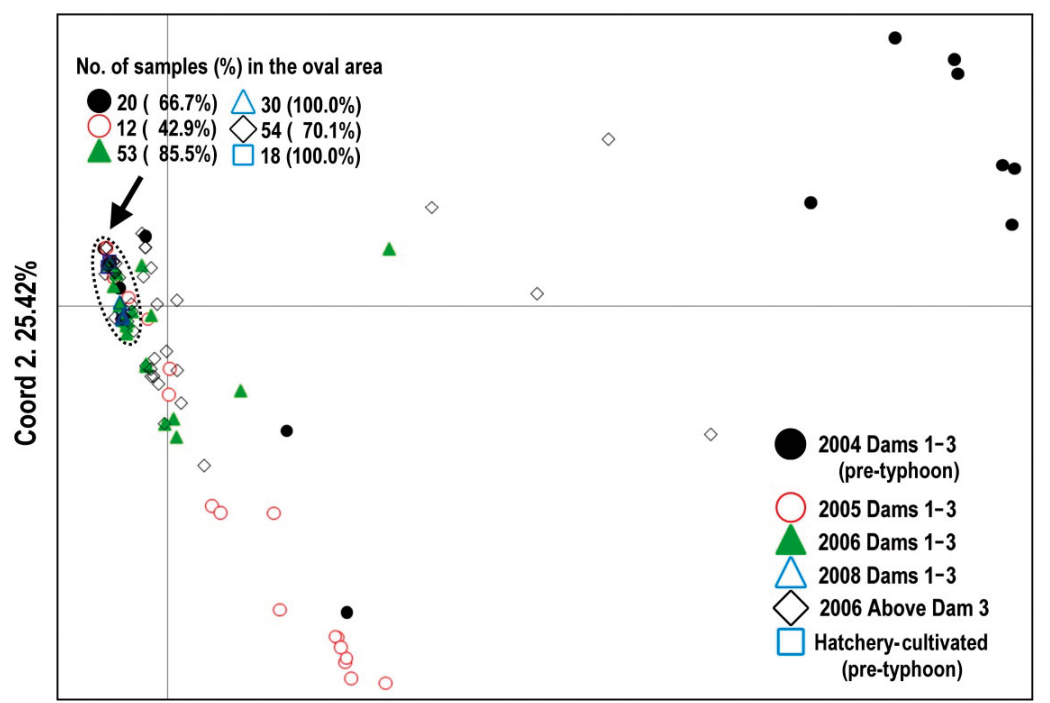

Coord $1.42 .15 \%$
Fig. 3. Plot of the first and second principal coordinates of amplified fragment length polymorphism genotypes for Formosa landlocked salmon Oncorhynchus formosanus during the $4 \mathrm{yr}$ of study (2004, 2005, 2006, and 2008) based on a similarity matrix using principal coordinate analysis $(\mathrm{PCoA})$. The first and second coordinates account for 42.15 and $25.42 \%$ of the total variation, respectively. All the hatcherycultivated individuals (pre-typhoon) and wild fish collected between Dams 1 and 3 in 2008 were concentrated in a small oval area (dotted line). A lower level of genetic diversity (variation) was found in hatcherycultivated individuals (pre-typhoon) and wild fish collected between Dams 1 and 3 in 2008 in comparison to the individuals collected in 2004 (pre-typhoon), 2005, and 2006 from either between Dams 1 and 3 or above Dam 3 above-dam sample in the first dimension (Coord. 1), and some of the below-dam 2005 sample cluster were in the second dimension (Coord. 2).

The Bayesian clustering analysis (STRUCTURE plot) clearly indicated 3 clusters ( $K=3$; purple, orange and blue) and a geographical pattern among sites and times (Fig. 4). Comparing the 1 (band present; red)/0 (band absent; grey) binary character matrix of polymorphic loci and the STRUCTURE analysis, the genotypes of the hatchery-cultivated population and wild fish collected between Dams 1 and 3 in 2008 were all in the blue cluster (band pres-

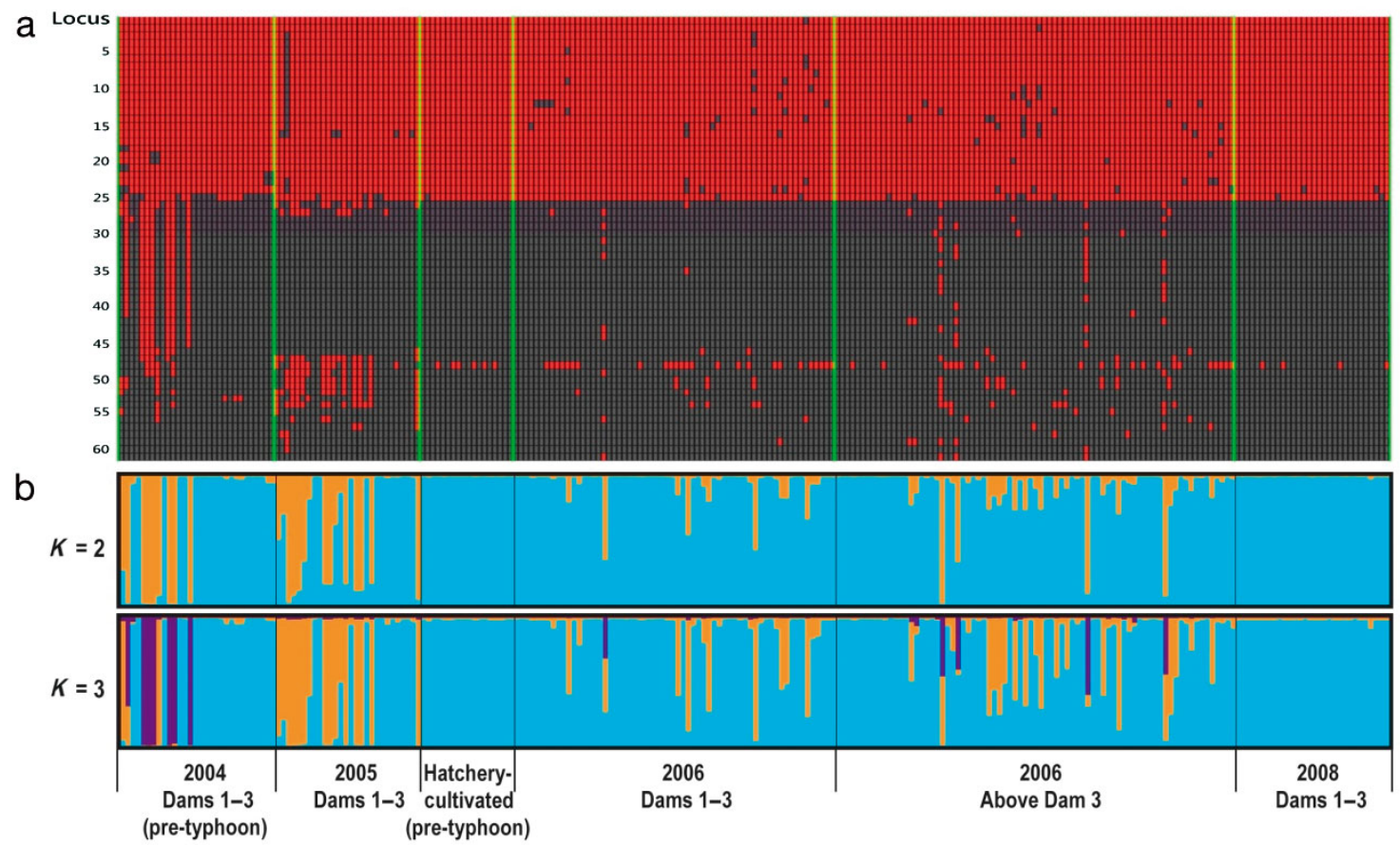

Fig. 4. (a) The 1 (band present; red)/0 (band absent; black) binary character matrix of polymorphic loci among all individuals of Formosa landlocked salmon Oncorhynchus formosanus in this study. (b) Estimated population structure based on the highest probability STRUCTURE run at $K=2$ and 3. Each individual is represented by a thin vertical line, which is partitioned into $K$ coloured segments that represent the individual's estimated membership fractions in each of the $K$ clusters. Populations are shown below the figure. Comparing binary character matrix and STRUCTURE analysis, the genotypes of the hatcherycultivated population and wild fish collected between Dams 1 and 3 in 2008 were all in the blue cluster (band present: loci 1 to 25 and band absent: loci 26 to 61 ) 
ent: loci 1 to 25; band absent: loci 26 to 61) (Fig. 4). Other genotypes were partially or completely in the purple and orange clusters that represent the individual's estimated membership fractions. However, genotypes belonging to the purple cluster were mainly wild fish collected between Dams 1 and 3 in 2004.

\section{DISCUSSION}

\section{Genetic structure of Formosa landlocked salmon}

To the best of our knowledge, this study provides the first molecular evidence for the decrease in genetic diversity that has occurred in the Formosa landlocked salmon subpopulations of the Chichiawan Stream. The study by Numachi et al. (1990) and our previous studies (Gwo et al. 2008, Hsu \& Gwo 2010, Hsu et al. 2010) using AFLP, microsatellite DNA and mtDNA, had all recognized the low genetic diversity among wild Formosa landlocked salmon. Before the massive escape from the hatchery in 2004, the wild population of Formosa landlocked salmon between Dams 1 and 3 had the highest genetic diversity $\left(H_{\mathrm{e}}=0.056\right)$ and the lowest average similarity index ( $S=0.968$ ) (Table 1). These values were much lower than those reported in other fish species (DeWoody \& Avise 2000), although heterozygosity values obtained are highly dependent on the marker used. In general, the genetic diversity of landlocked populations has been found to be lower than that of amphidoromous populations in masu salmon and other related fishes (Seki et al. 1999, DeWoody \& Avise 2000, Taniguchi 2003, Kakehi et al. 2005, Hsu et al. 2010). The striking genetic homogeneity of Formosa landlocked salmon could be the result of the bottleneck effect with a small effective population size (Numachi et al. 1990).

We also observed variable allele frequencies in the Formosa landlocked salmon population in this study (Fig. 2). Drastic changes in allele frequencies may be caused by a substantial random genetic drift, sampling error, a cohort effect, or a large-scale escape. Typhoons and storms frequently strike Taiwan (average 3.7 typhoon $\mathrm{yr}^{-1}$ ), and Formosa landlocked salmon have periodically undergone fluctuations in population size. Tzeng (2004) reported that the population size fluctuated drastically between 253 ind. in 1992 and 4221 in 2002, with an average of 1246 ind. over 18 yr (1987 to 2004) of census observations done by a visual counting method (snorkeling survey). The population size remained at fewer than 1000 ind. during the census period of this study. Apparently, when the population of Formosa landlocked salmon was at its lowest value, a large genetic drift might have occurred which altered the genetic composition of the population. Kawamura et al. (2007) also reported that random genetic drift caused striking genetic differentiation among amago salmon populations in small tributaries of River Koza, Japan, over a short period (40 yr).

Genetic diversity in the 2005 sample appears to have been less affected by the escape of hatchery fish in 2004 (Table 1, Figs. 2 \& 3). Formosa landlocked salmon are fluvatile, spending their entire life history in freshwater. The mature adult fish is small (about $15 \mathrm{~cm}$ ); males spawn when they are $1 \mathrm{yr}$ old, whereas females do not spawn until they are $2 \mathrm{yr}$ old. In contrast to the strict semelparity among Pacific salmon in North America, Formosa salmon are iteroparous (Healey et al. 2001), with a maximum age of spawning of about $4 \mathrm{yr}$ when the fish are about $30 \mathrm{~cm}$ in fork length (although some fish may live longer; Dai 1992). Mature females produce between 200 and 500 eggs during each spawning event (Dai 1992, Liao 2008). Thus, the cohort effect may explain the apparent time lag in the effect of the 2004 mass escape.

\section{Genetic effects of domesticated escape}

Although the striking genetic homogeneity of Formosa landlocked salmon could have been caused by a substantial random genetic drift, it is most likely the result of improper hatchery practices (i.e. a low number of founders) and the mass escape of hatcheryreared salmon. Although we did not examine the genetic diversity of all escaped fish, we expect that the escaped fish possessed little genetic diversity based on the low number of founders (5 pairs). Hatchery-cultivated Formosa landlocked salmon (pre-typhoon) had the lowest number of polymorphic bands (2, locus 25 and 48) among all the fish populations investigated (Fig. 2). Comparing the allele frequency of all populations, almost all polymorphic loci (with the exception of locus 25 and locus 48 ) became monomorphic after the mass escape (Fig. 2). However, the wild fish above Dam 3 (i.e. those that were not affected by the escaped fish) appear to have a greater genetic diversity than that of the fish in the area between Dams 1 and 3 in 2006 (Table 1, Figs. 1b $\& 2$ ). Therefore, it is unlikely that substantial random genetic drift is the main cause of the loss of genetic diversity in wild fish between Dams 1 and 3. 
Salmonid hatchery programs have been the topic of much debate over the last few decades. Most studies agree that releases can have detrimental effects on wild populations (Levin et al. 2001, Kaeriyama 2008, Buhle et al. 2009, Araki \& Schmid 2010, Jensen et al. 2010) since farmed salmon differ genetically from wild populations due to founder effects, artificial domestication selection and genetic drift (Allendorf \& Luikart 2007, Araki et al. 2009). In addition, loss of genetic diversity can occur when the effective number of parents is $<100$ (Cloud \& Thorgaard 1993, Allendorf \& Luikart 2007), as can occur in aquaculture operations. The release of hatchery-raised salmon can have various ecological effects, including predation and competition with native species as well as hybridization and the introduction of diseases to wild fish. Thus, the accumulated data suggest that the release of hatchery fish may be hastening the demise of wild stocks (Hilborn \& Eggers 2000, 2001, Allendorf \& Luikart 2007, Araki et al. 2009). Lack of proper hatchery management strategies also appears to have led to the severe inbreeding and rapid decline in genetic diversity of the wild Formosa landlocked salmon.

Flooding occurs frequently in the Chichiawan Stream, but the annual mean flood discharge varied greatly from $2.6 \mathrm{~m}^{3} \mathrm{~s}^{-1}$ in 2003 (with only 1 flood occurring in that year), to $14.5 \mathrm{~m}^{3} \mathrm{~s}^{-1}$ (112 floods in 2005) (Chiu et al. 2008). Chiu et al. (2008) reported that the peak discharge $\left(609 \mathrm{~m}^{3} \mathrm{~s}^{-1}\right)$ and the number of floods that occurred in 2005 was the largest in the previous 10 yr discharge history of the Chichiawan Stream. Aquatic insects are the primary food for Formosa landlocked salmon (Chiu et al. 2008, Lin 2010), and Chiu et al. (2008) reported that as flood magnitude increased, the biomass and abundance of aquatic insects in the Chichiawan Stream decreased steadily from 2003 to 2005, with both being at their lowest levels in 2005.

The population of Formosa landlocked salmon in the entire Chichiawan Stream was at its lowest point in 2005 (523 ind.) (Lin 2010). Lin (2010) reported that the population fluctuated drastically over a $10 \mathrm{yr}$ period (2001 to 2010), varying between 523 ind. in 2005 and 5321 in 2008, with an average population size of 1400 fish. The carrying capacity of Formosa landlocked salmon in the entire $7 \mathrm{~km}$ Chichiawan Stream is estimated to be about 4800 ind., with most fish (>50 to $60 \%$ ) concentrated between Dams 1 and 3 (Lin 2010). In the winter of 2003, 2004, 2005, and 2006, there were 3042, 1593, 523, and 2270 fish, respectively, between Dams 1 and 3. In July 2004, 1648 fish were found in this area (Lin 2010). The carrying capacity of the environment is limited, thus competitive interactions between the wild and escaped fish can have negative consequences. If the carrying capacity of a stream has already been met by wild salmon, the addition of hatchery-produced fish will diminish the productivity of the group as a whole.

In conclusion, we presented molecular evidence of the low genetic diversity of wild Formosa landlocked salmon in the Chichiawan Stream, and documented that genetic diversity in the population decreased even further between 2004 and 2008. The loss of genetic diversity in the wild population was low in 2005, but since then it has continued to decrease. In 2005, the wild population experienced a drastic decline in population size caused by many flooding events. Judging from these phenomena, we hypothesize that the decline in the genetic diversity of the wild population was mainly caused by population bottlenecks in 2005, and that the genetic homogeneity that has occurred in the population since 2005 was caused by the breeding of the escaped hatchery fish, particularly during the period of low stream productivity in 2005.

Acknowledgements. Some of the DNA samples were provided by Dr. L. Y. Liao (Shei-Pa National Park, Taiwan). We are grateful to Drs. R. Burghardt (Texas A\&M University, USA) and C. Burridge (University of Tasmania, Australia) for kindly reviewing the manuscript. The work was supported by Shei-Pa National Park, Ministry of the Interior, Taiwan and National Science Council, Taiwan (NSC) under project number 98-2311-B-019-003-MY3 to J.C.G.

\section{LITERATURE CITED}

Allendorf FW, Luikart G (2007) Conservation and the genetics of populations. Blackwell Publishing, Oxford

Anonymous (2000) The workshop on conservation of the Taiwan masou salmon Salmo (Oncorhynchus) masou formosanus (Jordan \& Oshima). Taiwan endemic species research institute, Nantou

Araki H, Schmid C (2010) Is hatchery stocking a help or harm? Evidence, limitations and future directions in ecological and genetic surveys. Aquaculture 308(Suppl): $\mathrm{S} 2-\mathrm{S} 11$

Araki H, Cooper B, Blouin MS (2007) Genetic effects of captive breeding cause a rapid, cumulative fitness decline in the wild. Science 318:100-103

Araki H, Cooper B, Blouin MS (2009) Carry-over effect of captive breeding reduces reproductive fitness of wildborn descendants in the wild. Biol Lett 5:621-624

Behnke RJ, Koh TP, Needham PR (1962) Status of the landlocked salmonid fishes of Formosa with a review of Oncorhynchus masou (Brevoort). Copeia 1962:400-407

Bensch S, Åkesson M (2005) Ten years of AFLP in ecology and evolution: Why so few animals? Mol Ecol 14: 2899-2914 
Brown C, Day R (2002) The future of stock enhancements: lessons for hatchery practice from conservation biology. Fish Fish 3:79-94

Buhle ER, Holsman KK, Scheuerell MD, Albaugh A (2009) Using an unplanned experiment to evaluate the effects of hatcheries and environmental variation on threatened populations of wild salmon. Biol Conserv 142:2449-2455

> Chang HW, Yang JL, Huang HY, Gwo JC, Su YF, Wen CH, Chou YC (2009) A novel growth hormone 1 gene-derived probe for Oncorhynchus masou formosanus distinguished from the Oncorhynchus subspecies. Mol Cell Probes 23:103-106

> Chiu MC, Kuo MH, Sun YH, Hong SY, Kuo HC (2008) Effects of flooding on avian top predators and their invertebrate prey in a monsoonal Taiwan stream. Freshw Biol 53:1335-1344

Cloud JG, Thorgaard GH (1993) Genetic conservation of salmonid fishes. Plenum Press, New York, NY

Coyer JA, Hoarau G, Pearson G, Mota C and others (2011) Genomic scans detect signatures of selection along a salinity gradient in populations of the intertidal seaweed Fucus serratus on a $12 \mathrm{~km}$ scale. Mar Genomics 4:41-49

Dai YT (1992) Population ecology of Formosan landlocked salmon Oncorhynchus masou formosanus. PhD dissertation, National Taiwan University, Taiwan (in Chinese)

> DeWoody JA, Avise JC (2000) Microsatellite variation in animal populations, with special emphasis on marine, freshwater, and anadromous fishes. J Fish Biol 56:461-473

Dice LR (1945) Measures of the amount of ecologic association between species. Ecology 26:297-302

Earl DA, vonHoldt BM (2012) STRUCTURE HARVESTER: a website and program for visualizing STRUCTURE output and implementing the Evanno method. Conservation Genet Resour 4:359-361

Evanno G, Regnaut S, Goudet J (2005) Detecting the number of clusters of individuals using the software STRUCTURE: a simulation study. Mol Ecol 14:2611-2620

Falush D, Stephens H, Pritchard JK (2007) Inference of population structure using multilocus genotype data: dominant markers and null alleles. Mol Ecol Notes 7:574-578

> Gwo JC, Hsu TH, Lin KH, Chou YC (2008) Genetic relationship among four subspecies of cherry salmon (Oncorhynchus masou) inferred using AFLP. Mol Phylogenet Evol 48:776-781

> Healey M, Kline P, Tsai CF (2001) Saving the endangered Formosa landlocked salmon. Fisheries 26:6-14

Heggenes J, Beere M, Tamkee P, Taylor EB (2011) Estimation of genetic diversity within and among populations of Oncorhynchus mykiss in a coastal river experiencing spatially variable hatchery augmentation. Trans Am Fish Soc 140:123-135

Hilborn R, Eggers D (2000) A review of the hatchery programs for pink salmon in Prince William Sound and Kodiak Island, Alaska. Trans Am Fish Soc 129:333-350

Hilborn R, Eggers D (2001) A review of the hatchery programs for pink salmon in Prince William Sound and Kodiak Island, Alaska: response to comment. Trans Am Fish Soc 130:720-724

Ho HC, Gwo JC (2010) Salmo formosanus Jordan \& Oshima, 1919 (currently Oncorhynchus formosanus) (Pisces, SALMONIDAE, SALMONINAE): proposed conservation of the specific name. Bull Zool Nomencl 67:300-302

Ho HC, Shao KT (2011) Annotated checklist and type catalog of fish genera and species described from Taiwan. Zootaxa 2957:1-74
Holsinger KE, Lewis PO (2007) Hickory: a package for analysis of population genetic data v1.1. Department of Ecology and Evolutionary Biology, University of Connecticut, Storrs, CT

> Hsu TH, Gwo JC (2010) A PCR-based method for sex identification of critically endangered Formosa landlocked salmon. Fish Sci 76:613-618

Hsu TH, Wang ZY, Takata K, Onozato H, Hara T, Gwo JC (2010) Use of microsatellite DNA and AFLP for cherry salmon (Oncorhynchus masou) complex identification. Aquac Res 41:e316-e325

Jan RQ, Jaung LC, Lin YS, Chang KH (1990) A morphometric and meristic study of the landlocked salmon in Taiwan, in comparison with other members of the genus Oncorhynchus (Salmonidae). Bull Inst Zool Acad Sin 29: 41-59

Jensen Ø, Dempster T, Thorstad EB, Uglem I, Fredheim A (2010) Escapes of fishes from Norwegian sea-cage aquaculture: causes, consequences and prevention. Aquacult Environ Interact 1:71-83

Jordan DS, Oshima M (1919) Salmo formosanus, a new trout from the mountain streams of Formosa. Proc Acad Nat Sci Philadelphia 71:122-124

Kaeriyama M (2008) Ecosystem-based sustainable conservation and management of Pacific salmon. In: Tsukamoto K, Kawamura T, Takeuchi T, Beard TD Jr, Kaiser MJ (eds) Fisheries for global welfare and environment: memorial book of the $5^{\text {th }}$ World Fisheries Congress 2008. TerraPub, Tokyo, p 371-380

Kakehi Y, Nakayama K, Watanabe K, Nishida M (2005) Inheritance of amplified fragment length polymorphism markers and their utility in population genetic analysis of Plecoglossus altivelis. J Fish Biol 66:1529-1544

Kawamura K, Kubota M, Furukawa M, Harada Y (2007) The genetic structure of endangered indigenous populations of the amago salmon, Oncorhynchus masou ishikawae, in Japan. Conserv Genet 8:1163-1176

Kitanishi S, Edo K, Yamamoto T, Azuma N, Hasegawa O, Higashi S (2007) Genetic structure of masu salmon (Oncorhynchus masou) populations in Hokkaido, northernmost Japan, inferred from mitochondrial DNA variation. J Fish Biol 71(Suppl C):437-452

> Kopelman NM, Mayzel J, Jakobsson M, Rosenberg NA, Mayrose I (2015) CLUMPAK: a program for identifying clustering modes and packaging population structure inferences across K. Mol Ecol Resour, doi:10.1111/17550998.12387

Kottelat M (1996) Oncorhynchus formosanus. The IUCN Red List of Threatened Species, version 2010.1. www. iucnredlist.org/details/15323/0 (accessed 5 June 2011)

> Levin PS, Zabel RW, Williams JG (2001) The road to extinction is paved with good intentions: negative association of fish hatcheries with threatened salmon. Proc R Soc Lond B 268:1153-1158

Liao LY (2008) Studies on the reproductive character of Formosa landlocked salmon. Shei-Pa National Park Adminstration, Taichung (in Chinese)

Lin HJ (2010) Long-term ecological monitoring and ecosystem modeling in the Wulin area. Shei-Pa National Park Adminstration, Taichung (in Chinese)

> Lin JY, Chen YC, Tsao HS, Yang HC (2006) Restoration of Formosan landlocked salmon habitat as refuge during high flows. JSCE-Doboku Gakkai Ronbunshuu D 62: 320-329

Lin YS, Tsao SS, Chang KH (1990) Population and distribu- 
tion of the Formosan landlocked salmon (Oncorhynchus masou formodanus) in Chichiawan Stream. Bull Inst Zool Acad Sin 29:73-85

Liu ZJ, Cordes JF (2004) DNA marker technologies and their applications in aquaculture genetics. Aquaculture 238: $1-37$

Naish KA, Taylor JE III, Levin PS, Quinn TP, Winton JR, Huppert D, Hilborn R (2007) An evaluation of the effects of conservation and fishery enhancement hatcheries on wild populations of salmon. Adv Mar Biol 53:61-194

Nakabo T (2009) Zoogeography of Taiwanese fishes. Korean J Ichthyol 21:311-321

Numachi KI, Kobayashi T, Chang KH, Lin YS (1990) Genetic identification and differentiation of Formosan salmon, Oncorhynchus masou formosanus, by restriction analysis of mitochondrial DNA. Bull Inst Zool Acad Sin 29:61-72

Peakall R, Smouse PE (2006) GenAlEx 6: genetic analysis in Excel. Population genetic software for teaching and research. Mol Ecol Notes 6:288-295

Ryman N, Laikre L (1991) Effects of supportive breeding on the genetically effective population size. Conserv Biol 5: 325-329

Editorial responsibility: Eric Gilman,

Honululu, Hawaii, USA
Sambrook J, Russell DW (2000) Molecular cloning: a laboratory manual. Cold Spring Harbor Laboratory, New York, NY

Seki S, Agresti JJ, Gall GAE, Taniguchi N, May B (1999) AFLP analysis of genetic diversity in three populations of ayu Plecoglossus altivelis. Fish Sci 65:888-892

Taniguchi N (2003) Genetic factors in broodstock management for seed production. Rev Fish Biol Fish 13:177-185

Teng FT (1959) On morphology and ecology of Formosa landlocked salmon. Bull Taiwan Fish Res Inst 5:77-82 (in Chinese)

Tzeng CS (2004) Studies on population ecology of the Formosa landlocked salmon, Oncorhynchus masou formosanus. Shei-Pa National Park Adminstration, Taichung (in Chinese)

Tzeng CS, Lin YS, Lin SM, Wang TY, Wang FY (2006) The phylogeography and population demographics of selected freshwater fishes in Taiwan. Zool Stud 45:285-297

Watanabe M, Lin Y (1985) Revision of the salmonid fish in Taiwan. Bull Biogeogr Soc Japan 40:75-85

Weir BS, Cockerham CC (1984) Estimating F-statistics for the analysis of population structure. Evolution 38:1358-1370

Submitted: January 5, 2015; Accepted: March 27, 2015

Proofs received from author(s): April 28, 2015 